\title{
The recovery of metals from WEEE: state of the art and future perspectives
}

\author{
Marra A.*, Cesaro A. and Belgiorno V. \\ Fisciano (SA), Italy \\ Received: 13/02/2018, Accepted: 10/10/2018, Available online: 15/10/2018 \\ *to whom all correspondence should be addressed: e-mail: amarra@unisa.it \\ https://doi.org/10.30955/gnj.002626
}

SEED - Sanitary Environmental Engineering Division, Department of Civil Engineering, University of Salerno, via Giovanni Paolo II, 84084

\begin{abstract}
Metals are essential elements in the modern technology as they are widely used for several industrial applications such as the manufacturing of electronic devices. Besides common metals, such as copper, iron and aluminium, electronic appliances can contain precious metals as well as metals defined as critical, including rare earth elements (REEs). In this regard, the chance to recycle metals from end-of-life appliances, namely Waste Electrical and Electronic Equipment (WEEE), has benefits for both the economy and the environment in terms of its protection and conservation. However, the existing recycling industry for the recovery of metals from WEEE is still in its infant stage and mostly addressed to the recovery of base metals; precious metals are also extracted, while REEs are practically almost never recycled.
\end{abstract}

The present work provides a comprehensive overview of the recycling technologies currently applied for the recovery of metals from WEEE, including the recovery of REEs, for which few and fragmented information is available in literature due to the limited experience and the restriction imposed by trade secrets. Advantages as well as limits of both conventional technologies and recent research developments are discussed and future perspectives are lastly pointed out.

Keywords: Recycling techniques, mechanical treatments, pyrometallurgy, hydrometallurgy, biometallurgy, precious metals, rare earth elements.

\section{Introduction}

The challenge to face the increasing demand of raw materials and the scarcity of primary resources has forced the transition from the take-make-dispose linear model towards a circular economy approach that conversely is based on the idea of closed loops and the reintroduction of resources into the economic system, promoting waste reuse and recycling. In this approach, metals appear the perfect materials for a circular economy model as they can be recycled countless times. Moreover, metal recycling from end-of-life materials can become more beneficial as some manufactured products contain metals in concentrations higher than that present in primary ores, as for Waste Electrical and Electronic Equipment (WEEE) (Hagelüken et al., 2016).

WEEE is the term used to denote a variety of end-of-life equipment coming from obsolete electrical appliances and electric goods (Kaya, 2016). Such a wide range of items is mainly composed of metals which contribute for the $60 \%$ of the equipment weight (Widmer et al., 2005). The major fraction of metals is concentrated in WEEE specific components, namely the printed circuit boards (PCBs), that besides copper, lead and tin solders contain also precious metals (Ghosh et al., 2015). Furthermore, some products comprising phosphors, as fluorescent lamps, neodymium-iron-boron (NdFeB) magnets and nickel-metal hybrid (NiMH) batteries contain rare earth elements (REEs), counting lanthanides plus Scandium and Yttrium (Binnemans et al., 2013; Tunsu et al., 2015). These elements were classified in 2010 by the European Commission as the most critical raw materials for their high economic importance and shortage production. Their criticality assessment has been confirmed in 2014 (European Commission, 2010, 2014).

The value of the metallic fraction is the main driver for WEEE recycling (Wang and $\mathrm{Xu}, 2014$ ). In the recycling chain for metal recovery, WEEE is primarily separately collected; then mechanical treatments are employed to detach the non-metallic fraction from the metallic one which is further sent to metallurgical refining processes in order to obtain the recovered metal (Cui and Zhang, 2008). However, the existing WEEE recycling industry is at the beginning and there is significant room for improvements for the recovery of precious metals and, especially, of REEs which are currently recovered at very low percentages (Binnemans et al., 2013). Moreover, the existing technologies for WEEE recycling are mostly dominated by smelting processes or emerging hydrometallurgical treatments claimed to have several impacts on the environment due to the generation of secondary pollutants. In this respect, the development of environmental friendly and cost-effective treatments is strongly required (Cui and Zhang, 2008; Khaliq et al., 2014; Priya and Hait, 2017). 
This paper outlines the state of the art in metal recycling processes from WEEE. Conventional technologies, including mechanical treatments, pyrometallurgical and hydrometallurgical processes, are deeply discussed. Recent research developments in the field of biometallurgy are overviewed as well. The current recycling of REEs from WEEE is also pointed out, although the information available are limited and fragmented as only few applications are reported. The limits imposed by social behaviour, product design, and recycling technologies are highlighted and future perspective are finally provided.

\section{Management practices: the recycling of WEEE}

The increasing amount of WEEE annually generated (a growing rate of 3-5\% per year has been projected in Europe by Eurostat), the presence of hazardous substances in WEEE, which requires proper handling practices, as well as the presence of valuable and critical materials point out the importance to pursue a sustainable management of this complex waste stream (Rubin et al., 2014; Tanskanen, 2013; Tsydenova and Bengtsson, 2011).

In European Countries and in most high-income regions worldwide, regulations on WEEE management are enforced or under development. Reuse, remanufacturing, recycling, incineration and landfilling are the main options involved in the management of WEEE. According to the principles of "waste hierarchy" applied in the European Member States, the reuse of second hand electronic goods is encouraged as the first priority. The remanufacturing of the end-of-life electronic equipment, consisting in its rebuilding, repairing and restoring for producing a new or almost new equipment, covers the second option of the management priority, followed by material recovery via recycling techniques. Incineration and landfilling are finally considered the least management options (Cui and Zhang, 2008; Priya and Hait, 2017).

However, in some nations, especially developing countries, WEEE is still mostly handled by an informal sector, relying on unsafe and improper recycling practices such as open dumping, open burning and uncontrolled acid/cyanide leaching. This sector, consisting of small and backyard workshops, is primarily widespread in regions where laws on environmental pollution control are missing, labour costs are low and the demand of low-price secondary materials is high (Ongondo et al., 2011).

The recycling of WEEE represents an important management option in terms of WEEE treatment, in order to avoid the release into the environment of the potentially harmful substances in it contained, and in terms of resource recovery due to the presence in WEEE of metals, including precious metals and REEs (Cui and Zhang, 2008; Priya and Hait, 2017).

The value of metals is the leading incentive in WEEE recycling as metals can be eternally recycled maintaining their quality and functionality. Besides the economic value of the recoverable materials, metal recycling from WEEE can moreover lead to several benefits in terms of energy saving, environmental protection and resource conservation. Indeed, the extraction of metals from waste is less energy intensive than their mining as the metal concentration in certain equipment is higher than that in ores (i.e. for precious metals). Moreover, the environmental protection is persuaded since the recycling of metals reduces the environmental burdens related to primary mining and the environmental impacts owing to incineration and landfilling, preventing both the losses of valuable materials and the release of harmful substances into the environment. The conservation of resources is furthermore promoted, especially with regard to critical raw materials that are largely employed in the electronics industry (Cui and Zhang, 2008; Hageluken, 2006; Khaliq et al., 2014; Priya and Hait, 2017).

Currently the WEEE recycling chain includes three main steps: (i) collection, (ii) pre-treatments, (iii) end-refining processing (Meskers and Hagelüken, 2009; Tanskanen, 2013).

The collection of WEEE is the earlier stage of the recycling chain that determines the amount of materials entering the recovery process (Meskers and Hagelüken, 2009). For the successful implementation of a collection strategy, a high level of consumer awareness is required in order to make the electronic waste available for recycling (Tanskanen, 2013; Toffolet, 2016). For instance, a relevant quantity of obsolete small electronic goods, especially mobile phones, is still stored by consumers at home and thus kept out of their potential recovery or incorrectly disposed of together with municipal waste (Baldé et al., 2015). WEEE collection takes place locally and it is promoted by government policies, advertisement for public awareness and separate collection facilities installed at public places (Khaliq et al., 2014). Municipalities and citizens are the most important actors in WEEE collection procedures (Favot and Marini, 2013).

The pre-treatment of WEEE consists of operations aiming at selectively removing larger valuable and hazardous components as well as upgrading material fractions which are further routed to end-refining processes (Cui and Zhang, 2008). During pre-treatments re-usable parts and hazardous components are removed by dismantling and manually sorting. Then, the separation of the different material fractions (i.e. plastics and metals) is carried out using mechanical treatments (Khaliq et al., 2014). This step involves several costs as for the collection stage. Pre-treatments usually occur on a local or regional scale, depending on the presence of treatment facilities (Tanskanen, 2013).

The last step of the recycling chain is covered by endrefining treatments that process the recyclable fractions coming from the previous steps so as to fed back to the market the recovered materials. In this stage, non-metallic fractions resulting from the mechanical separation processes can be treated through processes as gasification, pyrolysis, supercritical fluid de-polymerization and hydrogenolytic degradation with the main 
aim of producing chemical substances and fuels (Khaliq et al., 2014). Metallic fractions are, instead, sent to further recovery via techniques coming from the metallurgical sector, such as pyrometallurgy and hydrometallurgy (Cui and Zhang, 2008). Conversely from both the collection and the pre-treatment step, end processes are able to produce profits owing to the sale of recovered materials. As end-refining processes require special techniques, they are generally implemented on national or international level (Tanskanen, 2013).

The choice of the suitable recycling technique is addressed by factors as metal grade, economic feasibility and environmental compatibility (Priya and Hait, 2017).

Although the treatment of WEEE has achieved a good degree of specialization in some European countries (Li et al., 2013), the recycling of metals from WEEE is still in its early stage (Huang et al., 2009; Priya and Hait, 2017) with recycling rates below $15 \%$ for precious metals (Hagelüken et al., 2016) and $1 \%$ for critical metals (Binnemans et al., 2013).

\section{Techniques for metal recovery from WEEE}

The recovery of metals from WEEE can be achieved through treatments based on physical, chemical and biological processes (Priya and Hait, 2017).

After being separately collected, WEEE is firstly dismantled and subjected to a manual sorting with the main aim to eliminate components containing hazardous substances and separate components holding valuable materials (i.e. PCBs or cables) so as to avoid their losses. Then, the waste is processed through mechanical treatments, namely size reduction and physical separation processes. These processes pursue the liberation of metals and their separation from the non-metallic fraction (Cui and Forssberg, 2003). The non-metallic fraction is usually sent to landfills or incinerators (Canal Marques et al., 2013) while metals are further routed to end-refining treatments, exploiting metallurgical techniques as pyrometallurgy or hydrometallurgy, for the effective recovery of metals. In order to obtain high purity metals, electrometallurgical processes, including electrowinning and electrorefining, are generally applied at the end of the recycling chain. These processes are based on the electrodeposition of metal concentrates in aqueous electrolytes or molten salts (Hoffmann, 1992; Sum, 1991; Veit et al., 2006).

Besides the debated treatments, in the last years biometallurgy has attracted great attention as promising technique for the recovery of metals from WEEE at lower costs and minor environmental impacts compared to the conventional treatments (Cui and Zhang, 2008; Khaliq et al., 2014; Priya and Hait, 2017). Moreover, emerging technologies in the field of electrochemistry, supercritical fluids, mechanochemistry and ionic liquids are being explored (Tan and Li, 2015; Wang et al., 2017).
A general scheme of the treatments currently involved in the recovery of metals from WEEE is plotted in Figure 1.

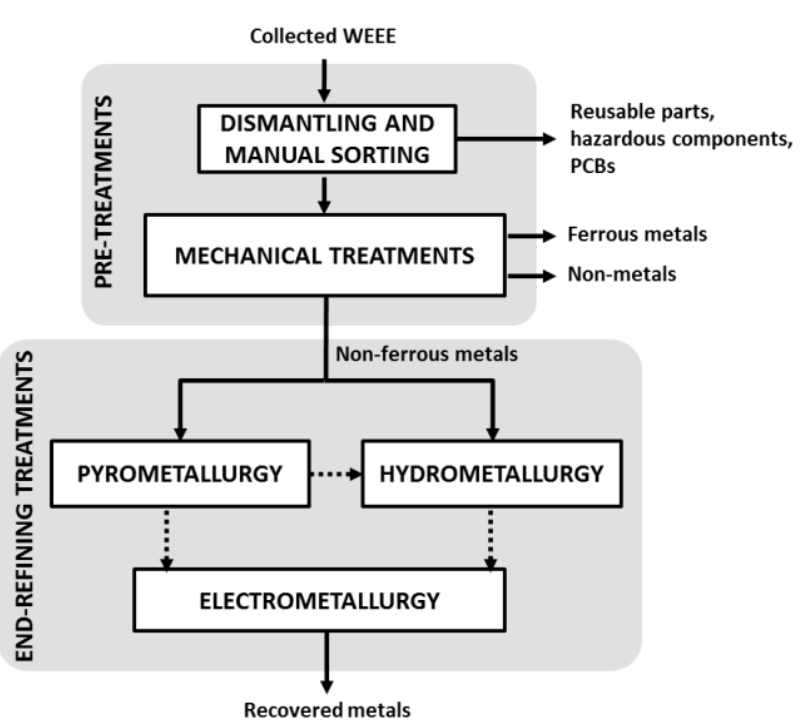

Figure 1. General scheme of the processes involved in WEEE metal recycling (adapted from Tuncuk et al., 2012)

\subsection{Mechanical treatments}

Mechanical treatments, along with dismantling and manual sorting, generally work as WEEE pre-treatments. The techniques employed for WEEE mechanical treatments have been transferred from the mineral sector (Menad, 2016). Shredding, screening, magnetic separation, eddy current separation, corona electrostatic separation and density-based separation can be found in a conventional WEEE mechanical treatment line (Figure 2).

Shredding is performed for obtaining a particle size reduction so as to achieve their liberation. Crushing/shearing machines or hammer mills are commonly used in WEEE treatments. After size reduction, the waste particles are further separated via selection techniques based on size, magnetic, electrical or density properties of the resulting shredded material ( $\mathrm{Yu}$ et al., 2009).

Screening is used for classifying shredded particles. WEEE screening is generally performed using vibrating screens and trommels. The screening process ensures the separation of the entering material at least into two separate fractions: the oversize material, namely the particles that are retained by the screen surface, and the undersize material, consisting of the particles which pass through the screen (Menad, 2016). At the end of this stage, output fractions uniformed in size as well as enriched in metals are returned (Cui and Forssberg, 2003).

Magnetic separation, eddy current separation and corona electrostatic separation base the selection criteria on the different electromagnetic properties of the material ( $\mathrm{Yu}$ et al., 2009). Magnetic separators, specifically low-intensity drum separators, allow the separation of ferromagnetic metals, as iron scraps, from non-ferrous metals and other 
non-magnetic materials (Cui and Forssberg, 2003). Eddy current separation and corona electrostatic separation provide the material selection based on the conductivity properties of the feeding waste materials. The former separation technique exploits alternative magnetic fields in order to generate eddy currents in non-ferrous particles. These currents induce in turn a secondary magnetic field which, reacting with the first one, results in repulsive forces able to separate the conducting particles from the product stream. The latter technique uses a high voltage electric field which provides the separation of metals from nonconductor materials as plastics (Menad, 2016).

Density-based techniques basically divide the coming stream into a light, a mixed and a heavy fraction. Pneumatic table or air table are the equipment commonly used (Menad, 2016). These techniques ensure the separation of metals from non-metals (Cui and Forssberg, 2003).

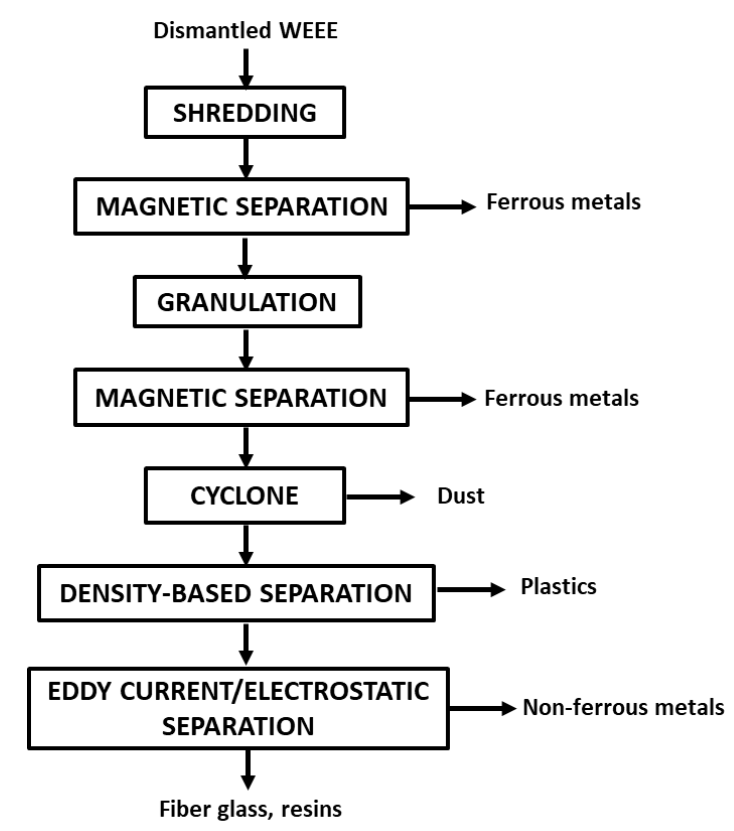

Figure 2. Mechanical treatment line for WEEE pre-processing (adapted from Lee et al., 2004)

As mechanical treatments determine the effective concentration of materials entering the further refining recovery processes, they play a fundamental role in the recycling chain (Chancerel et al., 2009; Meskers and Hagelüken, 2009; Meskers et al., 2009). In this regard, the amount of the output material obtained and its quality are important process parameters.

During pre-processing material losses can occur as $100 \%$ of recovery is an ideal situation. These losses can be related to several factors: (i) the type as well as the combination of the selection techniques; (ii) the thermodynamic of the process performed; (iii) an incorrect sorting which determines the presence of metals of interest in output streams not directly involved in the recovery process (Meskers and Hagelüken, 2009; Meskers et al., 2009). Moreover, the physical characteristics of the waste material, such as particle size and shape, can strongly affect the metal extraction as well as the process selectivity (Cui and Forssberg, 2003; Sun et al., 2015; Veit et al., 2002). For instance, Zhang and Forssberg (1997) highlighted that a comminution below $2 \mathrm{~mm}$ is sufficient to achieve a complete liberation of copper particles. The selectivity of the process is affected by the size of particles as separation techniques are characterized by a workable size particle ranges (Zhang and Forssberg, 1997). Moreover, the separation process is influenced by the shape of particles (Veit et al., 2002) and the product design (Bachér and Kaartinen, 2016).

Mechanical treatments are characterized by relative low capital and operating costs (Tuncuk et al., 2012). However, the main drawback is represented by the losses of valuable metals as well as significant dust generation (Kaya, 2016). Mechanical processes are well designed to recover mass relevant metals, as iron and copper, with yields up to $80 \%$ whereas they fail in the recovery of precious metals which are often lost in the dust streams (Bachér et al., 2015; Chancerel et al., 2009; Cui and Zhang, 2008; Lu and Xu, 2016; Oguchi et al., 2012; Veit et al., 2002). Previous investigations reported around $60-70 \%$ of losses in terms of gold and up to $80 \%$ of palladium. These losses are mainly ascribed to the shredding processes as they act dispersing precious metals in stream extraneous to metal recovery (Bachér et al., 2015; Chancerel et al., 2009; Marra et al., 2018a). Losses of critical metals have been stated as well. Habib et al. (2015) reported the complete losses of REEs contained in $\mathrm{NdFeB}$ magnets of hard disk drives (HDDs) in a shredding-based WEEE treatment plant. Ueberschaar et al. (2017) found large portions of cobalt and REEs in the ferrous fractions and in the fluffy shredder light fraction, from which recovery is not feasible, of a WEEE pre-processing plant. Similarly, Marra et al. (2018a) showed that after mechanical treatments REEs were almost concentrated in the dust fraction originating from process air cleaning.

The scientific and industrial research is, thus, currently directed towards the optimization of these processes in order to ensure the recovery of precious metals as well as REEs whose fate has not been addressed yet.

\subsection{Pyrometallurgy}

Pyrometallurgy is a consolidated technology in the field of extractive metallurgy that exploits heat and high temperatures to enable the recovery of metals. This technique has been effectively applied in the past two decades for the recovery of non-ferrous metals as well as precious metals from WEEE (Cui and Zhang, 2008).

The main pyrometallurgical processes include incineration, smelting, drossing, sintering, melting and reactions in a gas phase at high temperatures (Sum, 1991). Smelting is the prevalent route used for WEEE recycling (Zhang and $\mathrm{Xu}, 2016)$ : as copper and lead are the main components in electronic devices, copper and lead smelters are primarily used for the pyrometallurgical treatment of WEEE (Khaliq et al., 2014). 
During pyrometallurgical treatments, WEEE is fed and burned in specially designed incinerators, blast furnace or plasma arc furnace so as to remove the plastics contained in the electronic components whereas the metals are concentrated in a molten bath. The latter are casted as anode which is further refined using electrometallurgical processes for obtaining high purity metals. Slurry residues derived from this refining phase are rich in precious metals and are then processed for their recovery. A slag phase containing the extraneous materials is generated as well (Ebin and Isik, 2016). A schematic flowchart of WEEE recycling trough pyrometallurgical treatments is shown in Figure 3.

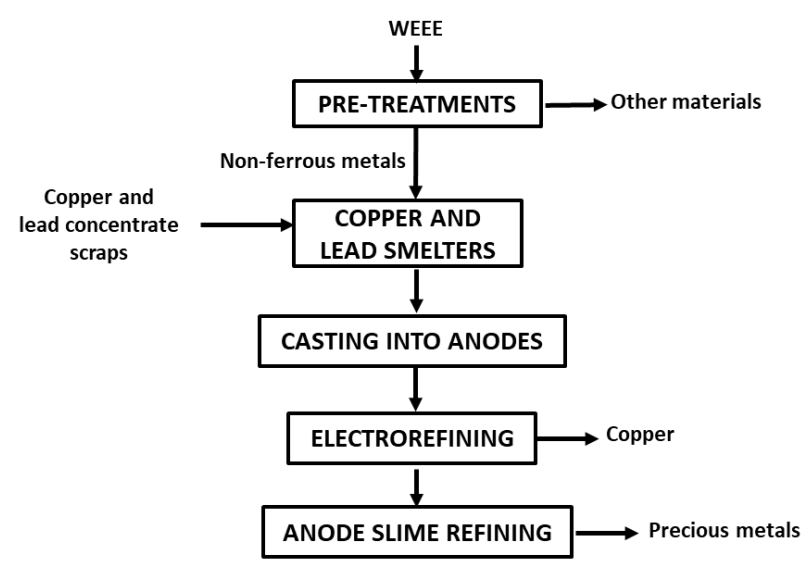

Figure 3. Flowchart of pyrometallurgical processes for WEEE recycling (adapted from Ebin and Isik, 2016)

Several smelting industrial technologies treating WEEE can be mentioned as well as some patented applications (Cui and Zhang, 2008). Among the industrial applications, the Noranda process employed at the Horne Smelter in Canada (Glencore recycling, 2018), the Kaldo technology developed by Boliden at the Rönnskår Smelter in Sweden (Boliden, 2018) and the IsaSmelt technology utilized by Umicore at the Hoboken Plant in Belgium (Umicore, 2018) are the most known.

The Horne Smelter located in Rouyn-Noranda, Quebec (Canada), is a custom copper smelter, processing 840,000 tons per year of copper and precious metal-bearing materials (Glencore recycling, 2018). Around $14 \%$ of the total material processed at the plant is represented by electronic scraps which are fed into the smelter together with the copper concentrates and the precious metal-bearing recyclable materials. The input materials are immersed in a molten bath at $1250^{\circ} \mathrm{C}$. Inside the reactor the smelting process generates two layers: a floating silica-based slag, within which lead, zinc and iron are entrapped as oxides, and a heavier lower layer consisting of copper matte. The collected copper matte is then sent to the converting process in order to have the blister copper that in turn is processed in an anode furnace to be casted as $99.1 \%$ pure anodes. The residual $0.9 \%$ comprises precious metals which are finally recovered via electrorefining.
The silica-based slag is refined as well in order to recovery other metals (Cui and Zhang, 2008; Khaliq et al., 2014).

The Boliden Ltd. Rönnskår Smelter in Sweden is an integrated copper and lead smelter which receives copper and lead concentrates as well as electronic scraps. In 2016 the plant processed a total of 840,000 tons of copper and lead concentrates and secondary materials, producing 207,000 tons of copper cathodes, 28,000 tons of lead, 33,000 tons of zinc clinker, 14 tons of gold, 508 tons of silver and 503,000 tons of sulphuric acid (Boliden, 2018). As of 2014, around 120,000 tons entering the plant are electronic waste (Ebin and Isik, 2016). The plant consists of two treatment lines, a copper production and a lead production line. The copper concentrates are processed through the copper production line, including a smelting and a converting process, whereas the electronic scraps are fed along with the lead concentrates in the lead production line. This line provides for a Kaldo furnace technology. The Kaldo converter releases two output products: a mixed copper alloy, which is integrated with the flow resulting from the smelter of the copper production line for further refining, and a lead alloy which is sent to refining as well. At the end of the copper line, metals as copper, silver, gold, platinum, palladium, nickel selenium and zinc are recovered whereas pure lead is obtained from the lead production line. The Kaldo furnace generates, moreover, dusts which are sent to separate refining operations for recovering metals such as lead, antimony, indium and cadmium. The smelting plant is also equipped with a line treating off-gas emissions that reduces the sulphur dioxides resulting from the smelting process in sulphuric acid and other sulphur products (Cui and Zhang, 2008; Ebin and Isik, 2016; Khaliq et al., 2014; Zhang and Xu, 2016).

The Umicore plant in Hoboken, Belgium, is an integrated smelter and refinery plant treating annually over 350,000 tons of feed-materials, including various industrial wastes, residues containing precious metals, spent industrial catalysts as well as car exhaust catalysts and PCBs (the plant is expanding its capacity from 350,000 to 500,000 tonnes per year). Electronic scraps represent around the $10 \%$ of the incoming feedstock. In total seventeen different metals, including base, precious and special metals, can be recovered at the end of the process: the plant has an annual production capacity of around 50 tons of platinum-group metals, 100 tons of gold and 2400 tons of silver. The recovery process is developed through two treatment lines: one aiming at the recovery of precious metals (precious metals operations, PMO) and the other one sets up for base metal recovery (base metal operations, BMO). The former line is equipped with a IsaSmelt furnace which produces three output products: (i) a copper bullion that is sent to further refining processes via leaching or electro-refining, (ii) a lead slag which is sent to the BMO line and (iii) sulphur gases that are fed to the sulphuric acid plant. The BMO line treats the high-grade lead concentrates and the lead slag resulting from the IsaSmelt furnace. This line consists in a lead blast furnace that produces both a lead bullion, further treated in the lead refinery with the aim of recovering special metals as 
indium, selenium and tellurium, and a copper matte which returns to the PMO line. The residue from the leaching and electrowinning process of the PMO line is finally treated for the recovery of precious metals (Cui and Zhang, 2008; Ebin and Isik, 2016; Hagelüken, 2006; Zhang and Xu, 2016).

Several high temperature processes, including melting, extraction with liquid magnesium, electroslag remelting, chlorination, fluorination, or electrolysis of molten salts have also been considered for the recovery of REEs from magnets and batteries (Binnemans et al., 2013). However, during pyrometallurgical processes REEs are lost into the slag phase in which they are easily entrapped due to the strong affinity of this group of metals with oxygen. In this regard, further electrometallurgical or hydrometallurgical processes are required so as to recover these elements from the slag (Binnemans et al., 2013; Haque et al., 2014). Notwithstanding the several research efforts in developing effective routes for REE recycling, pyrometallurgical applications at industrial scale are still limited. In 2011 Umicore and Rhodia developed the first industrial process for processing Nickel Metal Hydride (NiMH) rechargeable batteries. The developed process combines the metallurgical experience gained by the Umicore group and the REE refining competences of the Rhodia company. The batteries are processed using the patented Ultra High Temperature (UHT) smelting technology developed by Umicore. The UHT furnace in Hoboken has an installed capacity for treating 7,000 tons per year of Li-ion and $\mathrm{NiMH}$ batteries, equals to around $250,000,000$ mobile phone batteries, 2,000,000 e-bike batteries and 35,000 electricvehicle batteries (Umicore, 2018). A metal alloy and a slag are produced at the end of the smelting process: nickel is collected in the Ni-Co-Cu-Fe alloy whereas REEs end up in the slag phase together with oxides of calcium, aluminium, silicon and iron. The rare earth-bearing slag is then refined into rare earth materials at Rhodia's plant in La Rochelle (France) (Binnemans et al., 2013).

Over the years pyrometallurgy has confirmed to effectively recover metals from WEEE. Although this technology offers the advantage to treat any form of scraps (Ghosh et al., 2015), it is characterized by some drawbacks. The main environmental issue in pyrometallurgical processes is the generation of hazardous gaseous emissions. Moreover, the process requires high-energy supply which makes it sustainable only for high grade materials. In this view, mechanical treatments are needed as pre-treatment in order to process metal enriched components (Tuncuk et al., 2012; Zhang and Xu, 2016). Furthermore, aluminium and iron cannot be directly recovered using this process, as they are oxidized and collected in the slag phase. In addition, the outputs from pyrometallurgical processes need to be further refined through hydrometallurgical and/or electrochemical techniques in order to obtain the pure metal (Cui and Zhang, 2008; Tunsu et al., 2015).

\subsection{Hydrometallurgy}

Due to the several limits of pyrometallurgical applications, hydrometallurgy has received increasing interest as alternative route for the recovery of metals from WEEE.
Hydrometallurgy is more predictable and controllable than pyrometallurgy; moreover, it is characterized by low energy consumption and high recovery rates. No gaseous emissions are generated but large amounts of liquid effluents are produced as a result of the extraction procedure which involves toxic, corrosive and flammable reagents (Cui and Zhang, 2008; Tuncuk et al., 2012).

Hydrometallurgy generally includes a first leaching step, aiming to extract the metals of interest transferring them into the liquid solution, and a subsequent step directed to the separation of the metals in the leaching solution using techniques such as solvent extraction, precipitation and ion exchange (Tunsu and Retegan, 2016). Before the leaching step, a mechanical pre-treatment of the incoming WEEE is commonly required in order to enable the liberation of metals and their exposure to the lixiviant action as these elements are generally found in WEEE encapsulated by or covered with plastics or ceramics (Cui and Zhang, 2008; Sun et al., 2015). After the separation of the leached metals, a further refining process can be carried out via electrorefining, crystallization or chemical reduction, so as to obtain the pure recovered metal (Cui and Zhang, 2008). Figure 4 reports a general flowchart of hydrometallurgical processes for metal recovery from WEEE.

The leaching step assumes a key role in the hydrometallurgical process as it determines the metal transport from the solid matrix into the aqueous phase, affecting the yield of the entire treatment (Zhang et al., 2012). This step can be performed using acid or alkaline solutions.

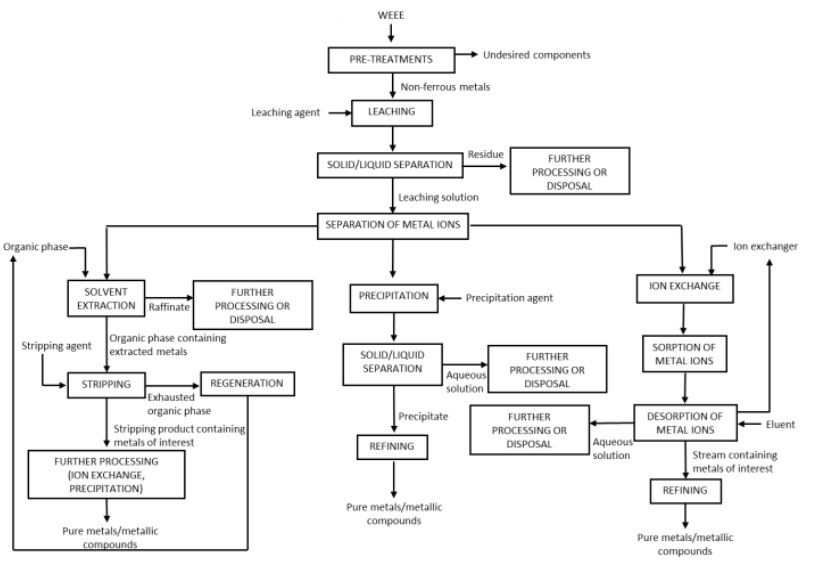

Figure 4. Flowchart of hydrometallurgical processes for WEEE recycling (adapted from Tunsu and Retegan, 2016)

Mineral acids, such as hydrochloric acid $(\mathrm{HCl})$, sulphuric acid $\left(\mathrm{H}_{2} \mathrm{SO}_{4}\right)$ and nitric acid $\left(\mathrm{HNO}_{3}\right)$, have been widely investigated for the extraction of base metals, especially copper, from PCBs. A strong oxidant, including $\mathrm{H}_{2} \mathrm{O}_{2}, \mathrm{O}_{2}$, $\mathrm{Fe}^{3+}$ and $\mathrm{Cl}_{2}$, is generally used in combination with these acids so as to enhance the extraction o metals (Tuncuk et al., 2012). Although the effectiveness of nitric and hydrochloric acid in metal leaching is well documented, these leaching agents are not suitable for industrial applications due to their corrosive nature. In comparison, sulphuric acid is less corrosive and less toxic and, therefore, more applicable at industrial scale. 
Moreover, $\mathrm{H}_{2} \mathrm{SO}_{4}$ is a cheap reagent and it showed good efficiency on base metal dissolution in presence of hydrogen peroxide (Birloaga et al., 2014; Oh et al., 2003; Yang et al., 2011). Organic acids (citric and oxalic acid) and alkaline solutions (ammonium and sodium hydroxide) have been used for the extraction of base metals as well (Birloaga et al., 2014; Pant et al., 2012).
Acid and alkaline solution have also been considered for leaching rare earth elements from both primary and secondary materials (Jha et al., 2016). In this regard, hydrochloric, nitric and sulphuric acid are the most used mineral acids in REE leaching (Tunsu et al., 2015). Several literature studies on leaching extraction of base metals and REEs from WEEE are included in Table 1.

Table 1. Studies on leachıng of base and rare earth metals from WEEE

\begin{tabular}{|c|c|c|c|}
\hline Leaching agent & Metal extracted (efficiency) & $\begin{array}{l}\text { Operating conditions ( } \mathrm{T}, \mathrm{S} / \mathrm{L} \text {, chemical } \\
\text { concentration, stirring rate, leaching } \\
\text { time) }\end{array}$ & References \\
\hline Nitric acid & $\mathrm{Cu}(95 \%)$ & $80^{\circ} \mathrm{C}, 33 \% \mathrm{w} / \mathrm{v}, 6 \mathrm{M} \mathrm{HNO}_{3}, 6 \mathrm{~h}$ & $\begin{array}{c}\text { Mecucci and Scott } \\
(2002)\end{array}$ \\
\hline Nitric acid & $\mathrm{Cu}(88.5-99.9 \%)$ & $70^{\circ} \mathrm{C}, 6 \% w / v, 2-3 \mathrm{M} \mathrm{HNO}_{3}, 2 \mathrm{~h}$ & Bas et al. (2014) \\
\hline Sulfuric acid & $\mathrm{Cu}, \mathrm{Fe}, \mathrm{Zn}, \mathrm{Ni}, \mathrm{Al}(95 \%)$ & $\begin{array}{c}85^{\circ} \mathrm{C}, 1 \% \mathrm{w} / \mathrm{v}, 2 \mathrm{M} \mathrm{H}_{2} \mathrm{SO}_{4}-0.2 \mathrm{M} \mathrm{H}_{2} \mathrm{O}_{2} \\
150 \mathrm{rpm}, 12 \mathrm{~h}\end{array}$ & Oh et al. (2003) \\
\hline Sulfuric acid & $\mathrm{Cu}(95 \%)$ & $\begin{array}{c}\text { Ambient temperature, } 10 \% w / v, 15 \% \\
\text { wt } \mathrm{H}_{2} \mathrm{SO}_{4}-10 \mathrm{~mL} 30 \% \mathrm{H}_{2} \mathrm{O}_{2}, 3 \mathrm{~h}\end{array}$ & Yang et al. (2011) \\
\hline Sulfuric acid & $\mathrm{Cu}(76.12 \%-90 \%)$ & $\begin{array}{c}30^{\circ} \mathrm{C}, 10 \% \mathrm{w} / \mathrm{v}, 2 \mathrm{M} \mathrm{H}_{2} \mathrm{SO}_{4}-20 \mathrm{ml} 30 \% \\
\mathrm{H}_{2} \mathrm{O}_{2}, 200 \mathrm{rpm}, 3 \mathrm{~h}\end{array}$ & Birloaga et al. (2013) \\
\hline Sulfuric acid & REEs (80\%) & $20^{\circ} \mathrm{C}, 10 \% \mathrm{w} / \mathrm{v}, 2 \mathrm{M} \mathrm{H}_{2} \mathrm{SO}_{4}, 2 \mathrm{~h}$ & Pietrelli et al. (2002) \\
\hline Sulfuric acid & Y (85\%) & $90^{\circ} \mathrm{C}, 20 \% w / v, 4 \mathrm{~N} \mathrm{H}_{2} \mathrm{SO}_{4}, 3 \mathrm{~h}$ & $\begin{array}{c}\text { De Michelis et al. } \\
\text { (2011) }\end{array}$ \\
\hline
\end{tabular}

Table 2. Studies on leaching of precious metals from WEEE

\begin{tabular}{|c|c|c|c|}
\hline Leaching agent & $\begin{array}{l}\text { Metal extracted } \\
\text { (efficiency) }\end{array}$ & $\begin{array}{l}\text { Operating conditions ( } \mathrm{pH}, \mathrm{T}, \mathrm{S} / \mathrm{L} \text {, chemical } \\
\text { concentration, stirring rate, leaching time) }\end{array}$ & References \\
\hline Cyanide & $\mathrm{Au}(95 \%)$ & $\mathrm{pH}>10,25^{\circ} \mathrm{C}$ & Quinet et al. (2005) \\
\hline Cyanide & $\mathrm{Au}(60-70 \%)$ & $\mathrm{pH} 12.5,25^{\circ} \mathrm{C}, 5 \% \mathrm{w} / \mathrm{V}$, potassium cyanide at $6-8 \%, 2-4 \mathrm{~h}$ & Petter et al. (2014) \\
\hline \multirow{2}{*}{ Thiourea } & $\mathrm{Ag}(94 \%)$ & \multirow{2}{*}{$\begin{array}{l}\mathrm{pH} \mathrm{1,} \mathrm{ambient} \mathrm{temperature,} 12.5 \% \mathrm{w} / \mathrm{v}, 10 \mathrm{~g} / \mathrm{L} \mathrm{CS}\left(\mathrm{NH}_{2}\right)_{2} \text {, } \\
500 \mathrm{rpm}, 2 \mathrm{~h}\end{array}$} & \multirow{2}{*}{ Ficeriová et al. (2008) } \\
\hline & $\mathrm{Au}(97 \%)$ & & \\
\hline \multirow{2}{*}{ Thiourea } & $\mathrm{Ag}(50 \%)$ & \multirow{2}{*}{$\mathrm{pH} 1,25^{\circ} \mathrm{C}, 24 \mathrm{~g} / \mathrm{L} \mathrm{CS}\left(\mathrm{NH}_{2}\right)_{2}, 2 \mathrm{~h}$} & \multirow{2}{*}{ Jing-ying et al. (2012) } \\
\hline & $\mathrm{Au}(90 \%)$ & & \\
\hline Thiourea & $\mathrm{Au}(69 \%)$ & $\begin{array}{l}\mathrm{pH} 1.4 \text {, ambient temperature, } 10 \% \mathrm{w} / \mathrm{v}, 20 \mathrm{~g} / \mathrm{L} \mathrm{CS}\left(\mathrm{NH}_{2}\right)_{2} \\
600 \mathrm{rpm}, 3.5 \mathrm{~h}\end{array}$ & Birloaga et al. (2013) \\
\hline Thiourea & $\mathrm{Au}(3.2 \mathrm{mg} / \mathrm{g})$ & $45^{\circ} \mathrm{C}, 0.3 \% w / v, 0.5 \mathrm{M} \mathrm{CS}\left(\mathrm{NH}_{2}\right)_{2}, 150 \mathrm{rpm}, 2 \mathrm{~h}$ & Gurung et al. (2013) \\
\hline Thiourea & $\mathrm{Ag}(6.8 \mathrm{mg} / \mathrm{g})$ & $60^{\circ} \mathrm{C}, 2 \% \mathrm{w} / \mathrm{v}, 0.5 \mathrm{M} \mathrm{CS}\left(\mathrm{NH}_{2}\right)_{2}, 150 \mathrm{rpm}, 2 \mathrm{~h}$ & Gurung et al. (2013) \\
\hline (Ammonium) & $\mathrm{Ag}(100 \%)$ & $\mathrm{pH} 10,40^{\circ} \mathrm{C}, 0.5 \% w / v, 0.2 \mathrm{M}\left(\mathrm{NH}_{4}\right)_{2} \mathrm{~S}_{2} \mathrm{O}_{3}, 250 \mathrm{rpm}, 24 \mathrm{~h}$ & \\
\hline Thiosulfate & $\mathrm{Au}(95 \%)$ & $(\mathrm{Ag})-48 \mathrm{~h}(\mathrm{Au})$ & Oh et al. (2003) \\
\hline $\begin{array}{l}\text { (Ammonium) } \\
\text { Thiosulfate }\end{array}$ & $\mathrm{Au}(98 \%)$ & $\mathrm{pH} 10,25^{\circ} \mathrm{C}, 0.12 \mathrm{M}\left(\mathrm{NH}_{4}\right)_{2} \mathrm{~S}_{2} \mathrm{O}_{3}, 200 \mathrm{rpm}, 2 \mathrm{~h}$ & Ha et al. (2010) \\
\hline $\begin{array}{l}\text { (Ammonium) } \\
\text { Thiosulfate }\end{array}$ & $\mathrm{Au}(90 \%)$ & $\mathrm{pH} 10,25^{\circ} \mathrm{C}, 0.12 \mathrm{M}\left(\mathrm{NH}_{4}\right)_{2} \mathrm{~S}_{2} \mathrm{O}_{3}, 200 \mathrm{rpm}, 10 \mathrm{~h}$ & Ha et al. (2010) \\
\hline \multirow{2}{*}{$\begin{array}{l}\text { (Ammonium) } \\
\text { Thiosulfate }\end{array}$} & $\mathrm{Ag}(93 \%)$ & \multirow{2}{*}{$\mathrm{pH} 9,40^{\circ} \mathrm{C}, 9 \% w / v, 0.5 \mathrm{M}\left(\mathrm{NH}_{4}\right)_{2} \mathrm{~S}_{2} \mathrm{O}_{3}, 500 \mathrm{rpm}, 48 \mathrm{~h}$} & \multirow{2}{*}{ Ficeriová et al. (2011) } \\
\hline & $\mathrm{Au}(98 \%)$ & & \\
\hline \multirow{2}{*}{$\begin{array}{l}\text { (Sodium) } \\
\text { Thiosulfate }\end{array}$} & $\mathrm{Ag}(3 \%)$ & \multirow{2}{*}{$\mathrm{pH} 9,25^{\circ} \mathrm{C}, 5 \% w / v, 0.1 \mathrm{M} \mathrm{Na}_{2} \mathrm{~S}_{2} \mathrm{O}_{3}, 4 \mathrm{~h}$} & \multirow{2}{*}{ Petter et al. (2014) } \\
\hline & $\mathrm{Au}(15 \%)$ & & \\
\hline Aqua regia & $\mathrm{Au}(100 \%)$ & $90^{\circ} \mathrm{C}, 50 \% \mathrm{w} / \mathrm{v}, 0.5 \mathrm{~h}$ & Sheng and Etsell (2007) \\
\hline \multirow{3}{*}{ Aqua regia } & $\mathrm{Ag}(7.2 \%)$ & \multirow{3}{*}{$20^{\circ} \mathrm{C}, 2.5 \% \mathrm{w} / \mathrm{v}, 3 \mathrm{~h}$} & \multirow{3}{*}{ Park and Fray (2009) } \\
\hline & $\mathrm{Au}(100 \%)$ & & \\
\hline & $\mathrm{Pd}(7.8 \%)$ & & \\
\hline
\end{tabular}


For the extraction of precious metals from WEEE, cyanide, thiourea, thiosulfate and halide are the leaching agents mainly studied (Cui and Zhang, 2008) (Table 2).

Generally the leaching of precious metals is carried out after the dissolution of base metals in order to improve the efficiency of the extraction process and reduce the impurities (Birloaga et al., 2013; Ghosh et al., 2015; Zhang et al., 2012).

Cyanidation has been used in the mining industry of gold for centuries due to its high efficiency and easily technical application as it is based on a simple process. The dissolution of gold is achieved through an electrochemical process: gold dissolves in the alkaline cyanide solution and forms gold cyanides as in the following equation (1) (Akcil et al., 2015):

$$
4 \mathrm{Au}+8 \mathrm{CN}^{-}+\mathrm{O}_{2}+2 \mathrm{H}_{2} \mathrm{O} \rightarrow 4 \mathrm{Au}(\mathrm{CN})_{2}^{-}+4 \mathrm{OH}^{-}
$$

The process is $\mathrm{pH}$ dependent. Optimum rates are reached at $\mathrm{pH}$ over 10.5 as in this condition "free cyanides" are mainly present in solution in form of cyanide anion $\left(\mathrm{CN}^{-}\right)$. Conversely at $\mathrm{pH}$ lower than 8.5, cyanide is present as aqueous hydrogen cyanide ( $\mathrm{HCN}$ ) which is volatile (Akcil et al., 2015). Cyanide complexes can be formed with other precious metals as well, following this order of activity: $\mathrm{Au}>\mathrm{Ag}>\mathrm{Pd}>\mathrm{Pt}$ (Cui and Zhang, 2008). Moreover, complexation can occur even with base metals. Thus, as copper and other common metals contained in WEEE may tie up cyanides making them no more available for gold dissolution, a chemical pre-treatment aiming at dissolving base metals is necessary. Same highlights can be even extended to the other lixiviant agents involved in precious metal dissolution (Akcil et al., 2015). However, the high toxicity related to cyanide and its environmental pressure have increased the interest for using non-cyanide lixiviants, as thiourea, thiosulfate and halide.

Thiourea $\left(\mathrm{CS}\left(\mathrm{NH}_{2}\right)_{2}\right)$, even known as sulfurized urea, is an organic complexing agent able to form soluble cationic complexes with gold under acidic conditions (Cui and Zhang, 2008; Zhang et al., 2012):

$$
\mathrm{Au}+2 \mathrm{CS}\left(\mathrm{NH}_{2}\right)_{2} \rightarrow \mathrm{Au}\left(\mathrm{CS}\left(\mathrm{NH}_{2}\right)_{2}\right)_{2}^{+}+\mathrm{e}
$$

Several research studies on thiourea leaching of precious metal from WEEE have demonstrated its promising application (Table 2) due to its faster kinetics and its lower toxicity compared to cyanide (Akcil et al., 2015). Conversely, thiourea has a very poor stability as it can be easily decomposed, leading to a high consumption of the reagent. In order to prevent thiourea decomposition, a suitable oxidant needs to be selected for obtaining the maximum oxidation of gold and the minimum oxidation of thiourea (Zhang et al., 2012). Ferric ions have been proved to be the most convenient oxidant (Birloaga et al., 2013). The greater consumption of the reagent and its higher cost make the process more expensive, hindering its application at full scale. A further limitation is represented by the final step of gold recovery which requires further developments (Cui and Zhang, 2008; Zhang et al., 2012).
Thiosulfate $\left(\mathrm{S}_{2} \mathrm{O}_{3}{ }^{2-}\right)$ has been investigated as cyanide substitute for precious metal leaching from electronic waste. Sodium and ammonium thiosulfate are the two kinds of thiosulfate commonly used (Zhang et al., 2012). The dissolution of gold in thiosulfate solution is an electrochemical reaction which requires the presence of ammonia and cupric ions in solution. Ammonia helps to stabilize the system in order to prevent the decomposition of thiosulfate whereas cupric ions act as a catalyst enhancing the gold dissolution. In this conditions, thiosulfate forms stable complexes with gold following the equations (3) and (4) (Cui and Zhang, 2008).

$$
\begin{aligned}
& \mathrm{Au}+5 \mathrm{~S}_{2} \mathrm{O}_{3}^{2-}+\mathrm{Cu}\left(\mathrm{NH}_{3}\right)_{4}^{2+} \\
& \quad \rightarrow \mathrm{Au}\left(\mathrm{S}_{2} \mathrm{O}_{3}\right)_{2}^{3-}+4 \mathrm{NH}_{3}+\mathrm{Cu}\left(\mathrm{S}_{2} \mathrm{O}_{3}\right)_{3}^{5-} \\
& 2 \mathrm{Cu}\left(\mathrm{S}_{2} \mathrm{O}_{3}^{2-}\right)+8 \mathrm{NH}_{3}+1 / 2 \mathrm{O}_{2}+\mathrm{H}_{2} \mathrm{O} \\
& \rightarrow 2 \mathrm{Cu}\left(\mathrm{NH}_{4}\right)_{4}^{2+}+2 \mathrm{OH}^{-}+6 \mathrm{~S}_{2} \mathrm{O}_{3}^{2-}
\end{aligned}
$$

Thiosulfate is less toxic and less expensive compared to cyanide. However, relatively low recovery rates and high reagent consumption are the main drawbacks of the process (Akcil et al., 2015).

Halide lixiviants include chloride, bromide and iodide solutions. Although high leaching rates have been reported, the use of these leaching agents is limited since they require special stainless steel and rubber-line equipment. Moreover, the formation of chlorine gases needs to be controlled as they are highly poisonous (Cui and Zhang, 2008). However, only chlorine has been currently applied at industrial scale. The mixture of hydrochloric acid and nitric acid in 3:1 ratio, known as aqua regia, has been successfully used for the extraction of precious metals from PCBs (Sheng and Etsell, 2007).

A critical comparison of the lixiviant agents used for precious metal recovery from WEEE was given by Cui and Zhang (2008). Considering the economic feasibility of the leaching process as a result of factors such as leaching rate, leaching kinetics, reagent cost and corrosive properties, cyanide results the best leaching agent. The assessment is overturned when the environmental impact due to the lixiviant toxicity is considered. However, in this investigation cyanide and thiourea got the same final results, although thiourea leaching is still at low research levels.

The leaching process is influenced by several factors, including type of leaching agent and its concentration, $\mathrm{pH}$, temperature, leaching time, stirring rate, ratio between the amount of solid and the leaching solution (S/L), size of solid particles and their mineral phase (Tunsu and Retegan, 2016).

Temperature is recognised to have a positive effect on kinetic reaction making it faster. However, the oxidative leaching has been successfully applied also at room temperature as an increasing in temperature resulted in the degradation of hydrogen peroxide in water and oxygen (Birloaga et al., 2014; Yang et al., 2011). Similarly, high temperature (above $40^{\circ} \mathrm{C}$ ) led to the decomposition of thiourea (Birloaga et al., 2013). 
Besides the effect of the leaching agents, temperature affects the dissolution of the chemical elements as well. For instance, elevated temperature decreased the solubility of rare earths in sulphuric acid solution leading to their precipitation (Tunsu et al., 2015). Ambient temperature is, moreover, desirable for economic aspects.

Regarding the stirring rate, a degradation of the oxidant was reported when the leaching process is carried out at high stirring rates. Thus, the oxidative leaching must be performed either without shaking or at low stirring rates. Conversely, higher shaking rates were necessary for acidic-thiourea leaching as the process depends on a strong mixing (Birloaga et al., 2013).

Optimum leaching conditions generally require smaller particle size as this ensure the exposure of larger metallic areas to the leaching agents (Birloaga et al., 2013).

The choice of the leaching agent influences not only the effectiveness of the extraction phase but also the technical feasibility of the separation step. For instance, an acidic lixiviant can foster the dissolution of many metallic species but the presence of a wide range of chemical complexes in solution as well as the presence of leached co-extractable compounds or unwanted precipitates can challenge the further separation of metal ions (Tunsu and Retegan, 2016).

Solvent extraction, ion exchange, precipitation/cementation are the common methods used for the separation of metal ions from leached solutions (Tuncuk et al., 2012).

Solvent extraction has been investigated for the selective recovery of copper from PCBs (Alam et al., 2007; Kinoshita et al., 2003; Lee et al., 2017; Yang et al., 2012). Studies focused on the recovery of precious metals from PCBs by means of cementation have been reported (Alam et al., 2007; Kamberović et al., 2009; Quinet et al., 2005). Solvent extraction and precipitation have also been used for recovering REEs from products containing phosphors, permanent magnets and batteries (Jha et al., 2016; Tunsu and Retegan, 2016; Tunsu et al., 2015).

Solvent extraction and ion exchange are methods preferred in presence of solutions containing many impurities whereas precipitation, cheaper and simpler, is feasible when co-precipitation is minimal. Compared to ion exchange, the solvent extraction is industrially preferable for the large range of extractant commercially available and the opportunity to have sequential extraction stages. Ion exchange can provide high product purity (>99.9\%) but it can be used for small feed owing to its high costs and the difficult to process large volume in a short time. However, due to the complex nature of WEEE including various substances, a combination of different extraction methods is in most cases required (Tunsu and Retegan, 2016).

Compared to the recovery of base metals, the hydrometallurgical recovery of precious metals and rare earth elements appears more attractive, due to their price, scarcity, low availability and high demand. However, despite the numerous studies carried out on hydrometallurgical processes for metal recovery from WEEE, their industrial application is still limited, especially with reference to critical metals. Moreover, in this field the information retrieval is hindered by competition as well as trade secrets. At full scale, hydrometallurgical treatments are currently integrated with pyrometallurgical or electrometallurgical processes such as at Hoboken plant (Umicore) and at La Rochelle plant (Rhodia) (Binnemans et al., 2013).

\subsection{Biometallurgy}

The environmental burdens related to both pyrometallurgical and hydrometallurgical processes have set the need for developing eco-friendly techniques for metal recovery from secondary materials. For this reason, great attention has been directed in the last years toward a low cost and minor impact technology named biometallurgy (Cui and Zhang, 2008; Das, 2010; Ilyas et al., 2010; Pant et al., 2012; Tuncuk et al., 2012).

Bioleaching and biosorption are the two main areas of biometallurgy (Cui and Zhang, 2008).

Bioleaching is a mature technique applied in mining industry for metal extraction from mineral sulphides and oxides, exploiting the capacity of some microorganism to solubilise metals as a result of bacterially assisted reactions. The first application dates back to the 1950s with regard to the extraction of copper but after the mid-1980s it has been extended also to other metals as gold (Brierley and Brierley, 2001). The extraction of these metals form mineral ores is performed at industrial scale piling the material and sprinkling the leaching water in it. Basically, three main procedures are used, consisting of dump leaching, heap leaching and underground or in situ leaching. The use of tank leaching has been tested as well (Bosecker, 1997).

Besides mineral ores, the ability of some microorganisms to enhance the mobilization and the dissolution of metals contained in solid matrices into their soluble form has been proved to be effective even for secondary sources as electronic waste (Beolchini et al., 2012). However, the bioleaching processes for metal recovery from WEEE are still at their infancy stage of development as electronic waste presents a form physically and chemically different from other solid waste. The literature studies available on WEEE bioleaching are currently limited (Ilyas and Lee, 2014) and mainly restricted at bench scale applications with only few attempts on column bioreactor at laboratory scale (Chen et al., 2015; Ilyas et al., 2010; Lee and Pandey, 2012).

WEEE bioleaching studies have been mostly focused on PCBs using autotrophic and heterotrophic microbes belonging to bacterial and fungal strains. The major microbes investigated include iron and sulfur-oxidizing chemolithotrophic acidophiles such as Acidithiobacillus and Leptospirullum, heterotrophs such as 
Chromobacterium and Pseudomonas, and fungi such as Aspergillus and Penicillium (Table 3).

Bioleaching processes for metal recovery from e-waste have been mainly targeted on the extraction of base metals as well as precious metals. Both autotrophic bacteria and heterotrophic microorganisms have been also used for REE leaching from native minerals (Brisson et al., 2016; Desouky et al., 2016; Ibrahim and El-Sheikh, 2011; Shin et al., 2015); however, only a limited number of studies is currently available on REE leaching from secondary sources (Beolchini et al., 2012; Muravyov et al., 2015; Qu and Lian, 2013) including electronic waste (Beolchini et al., 2012; Marra et al., 2018b; Reed et al., 2016). Notwithstanding, the REE microbe-interaction is not well understood (Barmettler et al., 2016).

The mechanism which governs the bioleaching process is still debated. In principle bioleaching can involve two dissolution mechanisms: direct bioleaching and indirect bioleaching. The former mechanism is based on the direct action of the bacteria that oxidize enzymatically the metal sulphide in sulphate via the intimate contact with the mineral surface. The latter mechanism provides the oxidation of metals through leaching agents biologically produced (Bosecker, 1997). Nevertheless, Sand et al. (2001) limited the bioleaching model only to the indirect mechanism proposing a pathways based on the production of sulphur intermediates, namely thiosulfate and polysulfide.

However, the bioleaching-based principles are recognised to be essentially attributed to: (i) oxidation-reduction reactions, (ii) production of organic and inorganic acids, (iii) excretion of microbial metabolites, chelators and complexing agents. Redoxolysis, acidolysis and complexolysis mechanisms are therefore responsible of metal bioleaching (Brandl, 2001; Priya and Hait, 2017) and can occur even simultaneously (llyas and Lee, 2014).

During bioleaching processes oxidation-reduction reactions take place. These reactions are catalysed by bacteria including iron-oxidizing strains which are able to oxidize ferrous iron $\left(\mathrm{Fe}^{2+}\right)$ in ferric iron $\left(\mathrm{Fe}^{3+}\right)$. Ferric ion is a powerful oxidizing agent $\left(E_{h}=0.77 \mathrm{~V}\right)$ that can attack metals, generally contained in the electronic waste in zero-valent form, converting them into their soluble form. Once metals are chemically oxidized, $\mathrm{Fe}^{3+}$ is again reduced to $\mathrm{Fe}^{2+}$. Then the generated $\mathrm{Fe}^{2+}$ is re-oxidizes in $\mathrm{Fe}^{3+}$ by bacteria in a continuous cycle following the reactions reported below (Bosecker, 1997):

$$
\begin{aligned}
& 2 \mathrm{Fe}^{2+}+0.5 \mathrm{O}_{2}+2 \mathrm{H}^{+} \stackrel{\text { Bacteria }}{\longrightarrow} 2 \mathrm{Fe}^{3+}+\mathrm{H}_{2} \mathrm{O} \\
& \mathrm{Fe}^{3+}+\mathrm{M}^{\circ} \rightarrow \mathrm{Fe}^{2+}+\mathrm{M}^{2+}
\end{aligned}
$$

where: $\mathrm{M}^{0}$ stands for metal.

The biogenic production of inorganic as well as organic acids contributes to the leaching of metals from WEEE. For instance, microorganisms as sulphur-oxidizing ones are able to produce sulfuric acid by the oxidation of elemental sulphur $\left(\mathrm{S}^{\circ}\right)$ providing protons for the hydrolytic attach of metals (Bosecker, 1997):

$$
\begin{aligned}
& \mathrm{S}^{0}+1.5 \mathrm{O}_{2}+\mathrm{H}_{2} \mathrm{O} \stackrel{\text { Bacteria }}{\longrightarrow} 2 \mathrm{H}^{+}+\mathrm{SO}_{4}^{2-} \\
& \mathrm{M}^{0}+\mathrm{H}_{2} \mathrm{SO}_{4}+0.5 \mathrm{O}_{2} \rightarrow \mathrm{M}^{2+}+\mathrm{SO}_{4}^{2-}+\mathrm{H}_{2} \mathrm{O}
\end{aligned}
$$

where: $\mathrm{M}^{0}$ stands for metal.

Besides inorganic acids, the dissolution of metals can be moreover assisted by organic acids, such as acetic, citric and oxalic acid produced by some heterotrophic bacteria and fungi. In this condition, both a mechanism of acidolysis and complexolysis can take place as some of these acids have chelating properties which lead to the formation of metallic complexes with the metals contained in the solid matrix (Ilyas and Lee, 2014).

Complexolysis is the general leaching mechanism that involves also the microbial metabolites excreted by some microbes. Bacteria strains as Chromobacterium violaceum and Pseudomonas fluorescent were found to solubilize gold from PCBs due to the secretion of biogenic cyanides forming complexes as follow (Priya and Hait, 2017):

$$
4 \mathrm{Au}+8 \mathrm{CN}^{-}+\mathrm{O}_{2}+\mathrm{H}_{2} \mathrm{O} \stackrel{\text { Bacteria }}{\longrightarrow} 4 \mathrm{Au}(\mathrm{CN})_{2}^{-}+4 \mathrm{OH}^{-}
$$

Complexation can take place in presence of rare earth cations $\left(\mathrm{RE}_{2} \mathrm{O}_{3}\right)$ and organic acids as well. For instance, oxalic acid fully dissociated in solution (equations 10-11) can form rare earths oxalate complexes as reported in equations 12-13 (Hassanien et al., 2013).

$$
\begin{aligned}
& \mathrm{C}_{2} \mathrm{H}_{2} \mathrm{O}_{4} \rightarrow\left(\mathrm{C}_{2} \mathrm{HO}_{4}\right)^{1-}+\mathrm{H}^{+} \\
& \mathrm{C}_{2} \mathrm{H}_{2} \mathrm{O}_{4} \rightarrow\left(\mathrm{C}_{2} \mathrm{O}_{4}\right)^{2-}+2 \mathrm{H}^{+} \\
& 3\left(\mathrm{C}_{2} \mathrm{HO}_{4}\right)^{1-}+\mathrm{RE}_{2} \mathrm{O}_{3} \rightarrow \mathrm{RE}\left(\mathrm{C}_{2} \mathrm{HO}_{4}\right)_{3} \\
& 3\left(\mathrm{C}_{2} \mathrm{O}_{4}\right)^{2-}+\mathrm{RE}_{2} \mathrm{O}_{3} \rightarrow \mathrm{RE}\left(\mathrm{C}_{2} \mathrm{O}_{4}\right)_{3}
\end{aligned}
$$

A bioleaching process is affected by various biotic factors as well as abiotic ones (Priya and Hait, 2017).

Biotic factors include type of microorganisms, inoculum size, maximum metal tolerance and adaptability of microbes to the e-waste toxicity (Ilyas and Lee, 2014; Priya and Hait, 2017). The most investigated group of bacteria in metal leaching from e-waste is represented by chemolithoautotrophic acidophilic bacteria, including Acidithiobacillus ferrooxidans, Acidithiobacillus thiooxidans and Leptospirillum ferroxidans. These microbes derive energy from oxidation of ferrous iron and reduced sulphur compounds. Besides autotrophic microorganisms, heterotrophs are exploited as well. They use organic carbon as energy source producing metabolites and organic acids able to leach out metals. The most used heterotrophic bacteria in WEEE bioleaching are Chromobacterium violaceum, Pseudomonas fluorescens and Pseudomonas aeruginosa, also known as cyanogenic bacteria whereas Aspergillus niger and Penicillium simplicissimum are the fungi mostly investigated (Ilyas and Lee, 2014; Priya and Hait, 2017). Compared to autotrophs, heterotrophic microorganisms can tolerate high $\mathrm{pH}$ conditions created by the alkaline nature of electronic waste and their ability of chelating metals represents an important advantage as the metal toxicity is reduced in solution by 
the formation of metal complexes (Burgstaller and Schinner, 1993). As greater amount of microorganisms involves faster leaching of metals, the size of inoculum was found to positively affect the leaching process (Yang et al., 2009) as well as the use of mixed cultures, instead of pure ones, that have been proved to have synergic effects resulting in more effective leaching rates (Brandl et al., 2001; llyas et al., 2007; şıldar et al., 2016).

Table 3. Bioleaching studies for metal recovery from WEEE
Moreover, a pre-growth strategy consisting in microorganism cultivation in absence of electronic waste demonstrated a more efficient metal mobilization due to the reduction of the toxic effects of the waste material for the microbes (Brandl et al., 2001; Işıldar et al., 2016). Conversely, a prolonged time of adaptation is needed (Brandl et al., 2001; llyas et al., 2007).

\begin{tabular}{|c|c|c|c|c|}
\hline & Microrganisms & Metal extracted (efficiency) & Leaching time & References \\
\hline \multirow{12}{*}{$\begin{array}{l}\text { Autotrophic } \\
\text { microbes }\end{array}$} & $\begin{array}{l}\text { A. ferrooxidans }+A \text {. } \\
\text { thiooxidans }\end{array}$ & $\mathrm{Al}, \mathrm{Cu}, \mathrm{Ni}, \mathrm{Zn}(90 \%)$ & $10 \mathrm{~d}$ & Brandl et al. (2001) \\
\hline & $\begin{array}{l}\text { S.thermosulfidooxidans + } \\
\text { acidophilic isolate }\end{array}$ & $\begin{array}{l}\text { Al (79\%), Cu (89\%), Ni (81\%), } \\
\text { Zn (83\%) }\end{array}$ & $18 \mathrm{~d}$ & Ilyas et al. (2007) \\
\hline & A. ferrooxidans & $\mathrm{Cu}(100 \%)$ & $4 \mathrm{~d}$ & Yang et al. (2009) \\
\hline & $\begin{array}{l}\text { A. ferrooxidans }+A \text {. } \\
\text { thiooxidans }\end{array}$ & $\mathrm{Cu}(90 \%)$ & $10 d$ & Liang et al. (2010) \\
\hline & Mixed Acidophilic bacteria & $\begin{array}{c}\text { Al (88.2\%), Cu (96.8\%), Zn } \\
(91.6 \%)\end{array}$ & $1.8-4 \mathrm{~d}$ & Zhu et al. (2011) \\
\hline & $\begin{array}{c}\text { A. ferrooxidans }+L \text {. } \\
\text { ferrooxidans }+A \text {. } \\
\text { thiooxidans }\end{array}$ & $\mathrm{Cu}(89 \%)$ & $4.8 \mathrm{~d}$ & Bas et al. (2013) \\
\hline & A. ferrooxidans & $\mathrm{Cu}(100 \%) \mathrm{Ni}(100 \%)$ & $20 d$ & Arshadi and Mousavi (2014) \\
\hline & A. ferrooxidans & $\begin{array}{c}\mathrm{Al}(75.4 \%), \mathrm{Cu}(96.8 \%), \mathrm{Zn} \\
(83.8 \%)\end{array}$ & $3 d$ & Yang et al. (2014) \\
\hline & $\begin{array}{l}\text { A. ferrooxidans }+A \text {. } \\
\text { thiooxidans }\end{array}$ & $\begin{array}{c}\text { Al }(20 \%), \mathrm{Cu}(100 \%), \mathrm{Ni} \\
(92 \%), \mathrm{Zn}(89 \%)\end{array}$ & $28 \mathrm{~d}$ & Mrazikova et al. (2015) \\
\hline & $\begin{array}{l}\text { A. ferrooxidans }+A \text {. } \\
\text { thiooxidans }\end{array}$ & $\mathrm{Cu}(98 \%)$ & $7 d$ & Işıldar et al. (2016) \\
\hline & $\begin{array}{c}\text { A. ferrooxidans }+A \text {. } \\
\text { thiooxidans }+L \\
\text { ferrooxidans }\end{array}$ & Y (70\%) & $16 \mathrm{~d}$ & Beolchini et al. (2012) \\
\hline & A. thiooxidans & $\begin{array}{c}\mathrm{Ce}, \mathrm{Eu}, \mathrm{Nd}(>99 \%), \mathrm{La}, \mathrm{Y} \\
(80 \%)\end{array}$ & $8 d$ & Marra et al. (2018b) \\
\hline \multirow{10}{*}{$\begin{array}{c}\text { Heterotrophic } \\
\text { microbes }\end{array}$} & Penicillium simplicissimum & $\begin{array}{c}\mathrm{Cu}(30 \%), \mathrm{Al}(60 \%), \mathrm{Ni} \\
(100 \%), \mathrm{Zn}(100 \%)\end{array}$ & $21 \mathrm{~d}$ & Brandl et al. (2001) \\
\hline & Apergillus niger & $\mathrm{Cu}(65 \%)$ & $21 \mathrm{~d}$ & Brandl et al. (2001) \\
\hline & C. violaceum & $\mathrm{Au}(14.9 \%)$ & $7 d$ & Faramarzi et al. (2004) \\
\hline & C. violaceum & $\mathrm{Au}(11.5 \%)$ & $7 \mathrm{~d}$ & Pham and Ting (2009) \\
\hline & P. fluorescens & $\mathrm{Au}(10.5 \%)$ & $7 d$ & Pham and Ting (2009) \\
\hline & C. violaceum & $\mathrm{Au}(69 \%)$ & $7 d$ & Pradhan and Kumar (2012) \\
\hline & C. violaceum $+P$. aeruginosa & $\mathrm{Au}(73 \%)$ & $7 d$ & Pradhan and Kumar (2012) \\
\hline & C. violaceum & $\mathrm{Au}(11.3 \%)$ & $8 d$ & Natarajan and Ting (2015) \\
\hline & P. putida & $\mathrm{Au}(44 \%)$ & $2 d$ & Işıldar et al. (2016) \\
\hline & P. putida & $\mathrm{Au}(48 \%)$ & $3 \mathrm{~h}$ & Marra et al. (2018b) \\
\hline
\end{tabular}

Abiotic factors influencing metal bioleaching consist of $\mathrm{pH}$, temperature, particle size of the solid matrix, leaching time, aeration or stirring rate and composition of leaching media (Ilyas et al., 2007; Wang et al., 2009). Metal leaching has been proved to be highly sensitive to $\mathrm{pH}$ (Yang et al., 2009). pH represents a fundamental parameter as it regulates the condition for optimum microorganism growth as well as for chemical metal solubilisation (Bosecker, 1997). Same consideration can be ascribed to temperature which is crucial for both microbial growth and metal dissolution. Microbes exploited in bioleaching processes belong mainly to mesophilic and thermophilic class: the formers act at temperature ranging between 25 - $30^{\circ} \mathrm{C}$ whereas the last mobilize metals at optimum temperature of $40-45^{\circ} \mathrm{C}$ (Ilyas et al., 2007). However, a recent investigation demonstrated the feasibility of leaching copper even at room temperature using a mixed culture

A. ferrooxidans and A. thiooxidans (Işıldar et al., 2016).

The characteristics of the source material affect the process as well. The size of solid particles influences the leaching process as it determines the material surface exposure to the leaching attack (Sun et al., 2015). Efficient metal leaching has been achieved using particle size ranging between 40-200 $\mu \mathrm{m}$ (Ilyas et al., 2007; Priya and Hait, 2017; Yang et al., 2009). The toxic nature of 
e-waste imposes the amount of solid in the pulp: a pulp density above $1-2 \% \mathrm{w} / \mathrm{v}$ generally resulted in the inhibition of the microbial growth (Beolchini et al., 2012; Marra et al., 2018b; Priya and Hait, 2017). Moreover, washing the solid material prior to bioleaching experiments in order to remove the non-metallic components could enhance the bioleaching performances (llyas et al., 2007).

Compared to chemical processes, bioleaching is recognised to require longer operation time. However, bioleaching processes exploiting cyanogenic bacteria were relatively faster than processes involving acidophiles (Table 3).

The bioleaching experiment needs to be carried out at shaking conditions providing enough aeration for microorganisms without producing friction and abrasion conditions due to an excessive agitation (Priya and Hait, 2017). Optimum stirring rate ranged between $120-175$ rpm (Beolchini et al., 2012; Ilyas et al., 2007; Yang et al., 2009).

The rate of bioleaching is, moreover, affected by the composition of the leaching media in terms of nutrients supporting the microbial growth. The concentration of $\mathrm{Fe}^{2+}$ as well as $\mathrm{S}^{0}$ influences the activity of autotrophic microorganisms (Ilyas et al., 2007; Yang et al., 2009; Zhu et al., 2011) due to its relevant role in bioleaching processes whereas the concentration of organic compounds regulates the growth of heterotrophs as for glycine with reference to cyanogenic bacteria (Işıldar et al., 2016).

In the field of biometallurgy, biosorption is the technique used to recover the leached metal ions from the solution. Biosorption is based on the ability of living as well as death biomass, including algae, fungi, yeast and bacteria, to bind the metal species present in solution. This process has been efficiently used for the removal and/or the recovery of metals from liquid effluents (Andrès et al., 2003; Das, 2010; Vijayaraghavan and Yun, 2008; Wang and Chen, 2009).

The biosorption mechanisms can be based on physical mechanisms, including electrostatic forces and ion exchange, and chemical mechanisms, such as complexation, chelation, microprecipitation, and microbial reduction (bioreduction), or a combination of them (Cui and Zhang, 2008).

Several biosorbents prepared from natural or waste biomass have been tested for metal recovery from WEEE. The recovery of precious metals from electronic waste has been investigated using bacteria (Creamer et al., 2006; Sheel and Pant, 2018) or biomass, such as eicchornia root, waste tea powder, persimmon tannin, chitosan (Bhat et al., 2012; Côrtes et al., 2015; Gurung et al., 2013). Studies on the recovery of REEs from WEEE by means of biosorption processes exploiting algae have also been reported (Kucuker et al., 2017).

Biometallurgical processes offer several advantages related to low capital costs, less environmental impacts and less energy consumption in comparison to conventional metallurgical technologies (Priya and Hait, 2017). Conversely, biometallurgy provides slow treatment kinetics resulting in a time consuming process (Pant et al., 2012). However, the application of biometallurgical technologies is of relevant interest especially for low grade material recovery. For instance, as REEs are contained in electronic waste at trace concentrations the recovery of these elements through biometallurgical approaches appears economically sustainable compared to conventional treatments (Beolchini et al., 2012).

Although some investigations have demonstrated the feasibility of biometallurgy in recovering metals from electronic waste, most of the applications are still at laboratory scale (Zhang and Xu, 2016) and the potential of metal recovery from WEEE through biometallurgical processes is yet to be fully explored (Ilyas and Lee, 2014), especially with reference to rare earth elements (Barmettler et al., 2016).

\section{Future perspectives}

The management of WEEE is a matter of great interest due to its increasing production rate and the handling issues related to its hazardous as well as valuable components.

Although the benefits of WEEE recycling are well-recognized, the effective recovery of materials from electronic waste is still challenged by technical, environmental, economic, social and cultural aspects:

- The heterogeneity and complexity of WEEE, the presence of hazardous substances and the low concentrations of critical materials pose technical obstacles for its recycling. Moreover, the component design and assembly often hinder its processing as for HDDs, in which the magnet, strongly glued to the bulk of the entire product, is hard to be separated (Tunsu and Retegan, 2016). In this regard, much room for improvements could be provided by eco-design strategies, addressing the design of the electronic device for its easier recycling (Ardente et al., 2014).

- Significant material losses are reported through the entire recycling chain owing to a poor waste collection and inadequate technical capacities of recycling infrastructures. At this point, the awareness of consumers can significantly contribute for an effective WEEE collection whereas progress in technologies should be directed towards the optimization of the current technologies and the development of integrated and advanced treatments to increase the recycling yields and extend the variety of metals that are effectively recycled (Hagelüken, 2012). Moreover, at this stage the development of environmentally friendly technologies is mandatory.

- Besides the technical feasibility, in recycling strategies the economic feasibility is also crucial. In this regard, the recycling should look at the market prices of the recovered materials that can fluctuate over time, especially for critical raw materials (Toffolet, 2016).

- For pursuing and promoting good recycling practices, virtuous cooperation and coordination among the stakeholders involved into the WEEE management system are fundamental as well as the role of regulations and policies, especially for limiting the 
amount of WEEE that is still illegally exported and managed by the informal sector (Tanskanen, 2013).

An integration of social, cultural, economic, environmental and technical aspects is, thus, a fundamental prerogative for developing an effective and sustainable management of WEEE.

\section{References}

Akcil A., Erust C., Gahan C.S., Ozgun M., Sahin M. and Tuncuk A. (2015). Precious metal recovery from waste printed circuit boards using cyanide and non-cyanide lixiviants - A review. Waste Management, 45, 258-271.

Alam M.S., Tanaka M., Koyama K., Oishi T. and Lee J.-C. (2007). Electrolyte purification in energy-saving monovalent copper electrowinning processes. Hydrometallurgy, 87, 36-44.

Andrès Y., Texier A.C. and Le Cloirec P. (2003). Rare earth elements removal by microbial biosorption: A review. Environmental Technology, 24, 1367-1375.

Ardente F., Mathieux F. and Recchioni M. (2014). Recycling of electronic displays: Analysis of pre-processing and potential ecodesign improvements. Resources Conservation Recycling, 92, 158-171.

Arshadi M. and Mousavi S.M. (2014). Simultaneous recovery of $\mathrm{Ni}$ and $\mathrm{Cu}$ from computer-printed circuit boards using bioleaching: Statistical evaluation and optimization. Bioresource Technology, 174, 233-242.

Bachér J. and Kaartinen T. (2016). Liberation of Printed Circuit Assembly (PCA) and dust generation in relation to mobile phone design in a size reduction process. Waste Management.

Bachér J., Mrotzek A. and Wahlström M. (2015). Mechanical pretreatment of mobile phones and its effect on the Printed Circuit Assemblies (PCAs). Waste Management, 45, 235-245.

Baldé C.P., Wang F., Kuehr R. and Huisman J. (2015). The Global Ewaste Monitor - 2014, United Nations University, IAS SCYCLE, Bonn, Germany.

Barmettler F., Castelberg C., Fabbri C., Brandl H. and Working Group of Environmental Microbiology, Department of Evolutionary Biology and Environmental Studies, University of Zurich, Winterthurerstrasse 190, CH-8057 Zurich, Switzerland (2016). Microbial mobilization of rare earth elements (REE) from mineral solids-A mini review. AIMS Microbiology 2, 190-204.

Bas A.D., Deveci H. and Yazici E.Y. (2013). Bioleaching of copper from low grade scrap TV circuit boards using mesophilic bacteria. Hydrometallurgy, 138, 65-70.

Bas A.D., Deveci H. and Yazici E.Y. (2014). Treatment of manufacturing scrap TV boards by nitric acid leaching. Separation and Purification Technology, 130, 151-159.

Beolchini F., Fonti V., Dell'Anno A., Rocchetti L. and Vegliò F. (2012). Assessment of biotechnological strategies for the valorization of metal bearing wastes. Waste Management, 32, 949-956.

Bhat V., Rao P. and Patil Y. (2012). Development of an integrated model to recover precious metals from electronic scrap - A novel strategy for e-waste management. Procedia-Social and Behavioral Sciences, 37, 397-406.

Binnemans K., Jones P.T., Blanpain B., Van Gerven T., Yang Y., Walton A. and Buchert M. (2013). Recycling of rare earths: a critical review. Journal of Cleaner Production, 51, 1-22.
Birloaga I., De Michelis I., Ferella F., Buzatu M. and Vegliò F. (2013). Study on the influence of various factors in the hydrometallurgical processing of waste printed circuit boards for copper and gold recovery. Waste Management, 33, 935941.

Birloaga I., Coman V., Kopacek B. and Vegliò F. (2014). An advanced study on the hydrometallurgical processing of waste computer printed circuit boards to extract their valuable content of metals. Waste Management, 34, 25812586.

Boliden (2018, February 12). Retrieved from https://www.boliden.com/operations/smelters/bolidenronnskar/

Bosecker K. (1997). Bioleaching: metal solubilization by microorganisms. FEMS Microbiology Reviews, 20, 591-604.

Brandl H. (2001). Microbial leaching of metals. In: Biotechnology Set, Rehm H.-J. and Reed G. (Eds.), Wiley-VCH Verlag GmbH Weinheim, Germany, pp. 191-224.

Brandl H., Bosshard R. and Wegmann M. (2001). Computermunching microbes: metal leaching from electronic scrap by bacteria and fungi. Hydrometallurgy, 59, 319-326.

Brierley J. and Brierley C. (2001). Present and future commercial applications of biohydrometallurgy. Hydrometallurgy, 59, 233-239.

Brisson V.L., Zhuang W.-Q. and Alvarez-Cohen L. (2016). Bioleaching of rare earth elements from monazite sand. Biotechnology and Bioengineering, 113, 339-348.

Burgstaller W. and Schinner F. (1993). Leaching of metals with fungi. Journal of Biotechnology, 27, 91-116.

Canal Marques A., Cabrera J.-M. and de Fraga Malfatti C. (2013). Printed circuit boards: A review on the perspective of sustainability. Journal of Environmental Management, 131, 298-306.

Chancerel P., Meskers C.E.M., Hagelüken C. and Rotter V.S. (2009). Assessment of precious metal flows during preprocessing of waste electrical and electronic equipment. Journal of Industrial Ecology, 13, 791-810.

Chen S., Yang Y., Liu C., Dong F. and Liu B. (2015). Column bioleaching copper and its kinetics of waste printed circuit boards (WPCBs) by Acidithiobacillus ferrooxidans. Chemosphere, 141, 162-168.

Côrtes L.N., Tanabe E.H., Bertuol D.A. and Dotto G.L. (2015). Biosorption of gold from computer microprocessor leachate solutions using chitin. Waste Management, 45, 272-279.

Creamer N.J., Baxter-Plant V.S., Henderson J., Potter M. and Macaskie L.E. (2006). Palladium and gold removal and recovery from precious metal solutions and electronic scrap leachates by Desulfovibrio desulfuricans. Biotechnology Letters, 28, 1475-1484.

Cui J. and Forssberg E. (2003). Mechanical recycling of waste electric and electronic equipment: a review. Journal of Hazardous Materials, 99, 243-263.

Cui J. and Zhang L. (2008). Metallurgical recovery of metals from electronic waste: A review. Journal of Hazardous Materials, 158, 228-256.

Das N. (2010). Recovery of precious metals through biosorption - A review. Hydrometallurgy, 103, 180-189.

De Michelis I., Ferella F., Varelli E.F. and Vegliò F. (2011). Treatment of exhaust fluorescent lamps to recover yttrium: Experimental and process analyses. Waste Management, 31, 2559-2568. 
Desouky O.A., El-Mougith A.A., Hassanien W.A., Awadalla G.S. and Hussien S.S. (2016). Extraction of some strategic elements from thorium-uranium concentrate using bioproducts of Aspergillus ficuum and Pseudomonas aeruginosa. Arabian Journal of Chemistry, 9, S795-S805.

Ebin B. and Isik M.I. (2016). Chapter 5 - Pyrometallurgical Processes for the Recovery of Metals from WEEE. In: WEEE Recycling, Chagnes A., Cote G., Ekberg C., Nilsson M. and Retegan T. (Eds.), Elsevier, pp. 107-137.

European Commission (2010). Report on Critical Raw Materials for the EU. Report of the Ad hoc Working Group on defining critical raw materials.

European Commission (2014). Report on Critical Raw Materials for the EU. Report of the Ad hoc Working Group on defining critical raw materials.

Faramarzi M.A., Stagars M., Pensini E., Krebs W. and Brandl H. (2004). Metal solubilization from metal-containing solid materials by cyanogenic chromobacterium violaceum. Journal of Biotechnology, 113, 321-326.

Favot M. and Marini A. (2013). A Statistical Analysis of Prices of Electrical and Electronic Equipment after the Introduction of the WEEE Directive: WEEE Directive and EEE Price Increase. Journal of Industrial Ecology, 17, 827-834.

Ficeriová J., Baláz P., Dutková E. and Gock E. (2008). Leaching of gold and silver from crushed Au-Ag wastes. Open Chemistry Journal, 2, 6-9.

Ficeriová J., Baláž P. and Gock E. (2011). Leaching of gold, silver and accompanying metals from circuit boards (PCBs) waste. Acta Montanistica Slovaca, 16, 128.

Ghosh B., Ghosh M.K., Parhi P., Mukherjee P.S. and Mishra B.K. (2015). Waste Printed Circuit Boards recycling: an extensive assessment of current status. Journal of Cleaner Production, 94, 5-19.

Glencore recycling (2018, February 12). Retrieved from http://www.glencorerecycling.com/en/RecyclingServices/rec ycling-operations/Pages/Horne-Smelter.aspx.

Gurung M., Adhikari B.B., Kawakita H., Ohto K., Inoue K. and Alam S. (2013). Recovery of gold and silver from spent mobile phones by means of acidothiourea leaching followed by adsorption using biosorbent prepared from persimmon tannin. Hydrometallurgy, 133, 84-93.

Ha V.H., Lee J., Jeong J., Hai H.T. and Jha M.K. (2010). Thiosulfate leaching of gold from waste mobile phones. Journal of Hazardous Materials, 178, 1115-1119.

Habib K., Parajuly K. and Wenzel H. (2015). Tracking the Flow of Resources in Electronic Waste - The Case of End-of-Life Computer Hard Disk Drives. Environmental Science \& Technology, 49, 12441-12449.

Hagelüken B.C. (2012). Recycling the Platinum Group Metals: A European Perspective. Platinum Metals Review, 56, 29-35.

Hageluken C. (2006). Improving metal returns and eco-efficiency in electronics recycling-a holistic approach for interface optimisation between pre-processing and integrated metals smelting and refining. In: Electronics and the Environment, 2006. Proceedings of the 2006 IEEE International Symposium On, IEEE, pp. 218-223.

Hagelüken C. (2006). Recycling of electronic scrap at Umicore precious metals refining. Acta Montanistica Slovaca, 12, 111120.
Hagelüken C., Lee-Shin J., Carpentier A. and Heron C. (2016). The EU circular economy and its relevance to metal recycling. Recycling, 1, 242-253.

Haque N., Hughes A., Lim S. and Vernon C. (2014). Rare earth elements: Overview of mining, mineralogy, uses, sustainability and environmental impact. Resources, 3, 614635.

Hassanien W.A.G., Desouky O.A.N. and Hussien S.S.E. (2013). Bioleaching of some rare earth elements from Egyptian monazite using Aspergillus ficuum and Pseudomonas aeruginosa. Walailak Journal of Science and Technology, 11, 809-823.

Hoffmann J.E. (1992). Recovering precious metals from electronic scrap. Journal of Management, 44, 43-48.

Huang K., Guo J. and Xu Z. (2009). Recycling of waste printed circuit boards: A review of current technologies and treatment status in China. Journal of Hazardous Materials, 164, 399-408.

Ibrahim H.A. and El-Sheikh E.M. (2011). Bioleaching treatment of Abu Zeneima uraniferous gibbsite ore material for recovering $\mathrm{U}, \mathrm{REEs}, \mathrm{Al}$ and $\mathrm{Zn}$. Research Journal of Chemical Science, 1, 55.

Ilyas S. and Lee J. (2014). Biometallurgical recovery of metals from waste electrical and electronic equipment: a review. ChemBioEng Reviews, 1, 148-169.

Ilyas S., Anwar M.A., Niazi S.B. and Afzal Ghauri M. (2007). Bioleaching of metals from electronic scrap by moderately thermophilic acidophilic bacteria. Hydrometallurgy, 88, 180188.

Ilyas S., Ruan C., Bhatti H.N., Ghauri M.A. and Anwar M.A. (2010). Column bioleaching of metals from electronic scrap. Hydrometallurgy, 101, 135-140.

Işıldar A., van de Vossenberg J., Rene E.R., van Hullebusch E.D. and Lens P.N.L. (2016). Two-step bioleaching of copper and gold from discarded printed circuit boards (PCB). Waste Management, 57, 149-157.

Jha M.K., Kumari A., Panda R., Rajesh Kumar J., Yoo K. and Lee J.Y. (2016). Review on hydrometallurgical recovery of rare earth metals. Hydrometallurgy, 161, 77.

Jing-ying L., Xiu-li X. and Wen-quan L. (2012). Thiourea leaching gold and silver from the printed circuit boards of waste mobile phones. Waste Management, 32, 1209-1212.

Kamberović Ž., Korać M., Ivšić D., Nikolić V. and Ranitović M. (2009). Hydrometallurgical process for extraction of metals from electronic waste, Part I: Material characterization and process option selection. Metalurgija, 15, 231-243.

Kaya M. (2016). Recovery of metals and nonmetals from electronic waste by physical and chemical recycling processes. Waste Management, 57, 64-90.

Khaliq A., Rhamdhani M., Brooks G. and Masood S. (2014). Metal extraction processes for electronic waste and existing industrial routes: A review and Australian perspective. Resources, 3, 152-179.

Kinoshita T., Akita S., Kobayashi N., Nii S., Kawaizumi F. and Takahashi K. (2003). Metal recovery from non-mounted printed wiring boards via hydrometallurgical processing. Hydrometallurgy, 69, 73-79.

Kucuker M.A., Wieczorek N., Kuchta K. and Copty N.K. (2017). Biosorption of neodymium on Chlorella vulgaris in aqueous solution obtained from hard disk drive magnets. PLOS One, 12, e0175255. 
Lee J. and Pandey B.D. (2012). Bio-processing of solid wastes and secondary resources for metal extraction - A review. Waste Management, 32, 3-18.

Lee C., Chang C., Fan K. and Chang T. (2004). An overview of recycling and treatment of scrap computers. Journal of Hazardous Materials, 114, 93-100.

Lee C.-H., Yen H.-Y., Liao C.-H., Popuri S.R., Cadogan E.I. and Hsu C.-J. (2017). Hydrometallurgical processing of $\mathrm{Nd}-\mathrm{Fe}-\mathrm{B}$ magnets for Nd purification. Journal of Material Cycles and Waste Management, 19, 102-110.

Li J., Lopez N., Brenda N., Liu L., Zhao N., Yu K. and Zheng L. (2013). Regional or global WEEE recycling. Where to go? Waste Management, 33, 923-934.

Liang G., Mo Y. and Zhou Q. (2010). Novel strategies of bioleaching metals from printed circuit boards (PCBs) in mixed cultivation of two acidophiles. Enzyme and Microbial Technology, 47, 322-326.

Lu Y. and Xu Z. (2016). Precious metals recovery from waste printed circuit boards: A review for current status and perspective. Resources Conservation Recycling, 113, 28-39.

Marra A., Cesaro A. and Belgiorno V. (2018a). Separation efficiency of valuable and critical metals in WEEE mechanical treatments. Journal of Cleaner Production, 186, 490-498.

Marra A., Cesaro A., Rene E.R., Belgiorno V. and Lens P.N.L. (2018b). Bioleaching of metals from WEEE shredding dust. Journal of Environmental Management, 210, 180-190.

Mecucci A. and Scott K. (2002). Leaching and electrochemical recovery of copper, lead and tin from scrap printed circuit boards. Journal of Chemical Technology and Biotechnology, 77, 449-457.

Menad N.-E. (2016). Chapter 3 - physical Separation Processes in Waste Electrical and Electronic Equipment Recycling. In WEEE Recycling, Chagnes A., Cote G., Ekberg C., Nilsson M. and Retegan T. (Eds.), Elsevier, pp. 53-74.

Meskers C. and Hagelüken C. (2009). The impact of different preprocessing routes on the metal recovery from PCs. In European Metallurgical Conference.

Meskers C.E.M., Hagelüken C., Salhofer S. and Spitzbart M. (2009). Proceedings: EMC 2009, European Metallurgical Conference: June 28 - July 1, 2009, Innsbruck, Austria. Vol. 1: Sustainable Development/Recycling, Hydrometallurgy, Clausthal-Zellerfeld, GDMB.

Mrazikova A., Marcincakova R., Kadukova J., Velgosova O. and Balintova M. (2015). Influence of used bacterial culture on zinc and aluminium bioleaching from printed circuit boards. Nova Biotechnologica et Chimica, 14.

Muravyov M.I., Bulaev A.G., Melamud V.S. and Kondrat'eva T.F. (2015). Leaching of rare earth elements from coal ashes using acidophilic chemolithotrophic microbial communities. Microbiology, 84, 194-201.

Natarajan G. and Ting Y.-P. (2015). Gold biorecovery from ewaste: An improved strategy through spent medium leaching with $\mathrm{pH}$ modification. Chemosphere, 136, 232-238.

Oguchi M., Sakanakura H., Terazono A. and Takigami H. (2012). Fate of metals contained in waste electrical and electronic equipment in a municipal waste treatment process. Waste Management, 32, 96-103.

Oh C.J., Lee S.O., Yang H.S., Ha T.J. and Kim M.J. (2003). Selective leaching of valuable metals from waste printed circuit boards.
Journal of the Air \& Waste Management Association, 53, 897902.

Ongondo F.O., Williams I.D. and Cherrett T.J. (2011). How are WEEE doing? A global review of the management of electrical and electronic wastes. Waste Management, 31, 714-730.

Pant D., Joshi D., Upreti M.K. and Kotnala R.K. (2012). Chemical and biological extraction of metals present in $E$ waste: $A$ hybrid technology. Waste Management, 32, 979-990.

Park Y.J. and Fray D.J. (2009). Recovery of high purity precious metals from printed circuit boards. Journal of Hazardous Materials, 164, 1152-1158.

Petter P.M.H., Veit H.M. and Bernardes A.M. (2014). Evaluation of gold and silver leaching from printed circuit board of cellphones. Waste Management, 34, 475-482.

Pham V.A. and Ting Y.P. (2009). Gold bioleaching of electronic waste by cyanogenic bacteria and its enhancement with biooxidation. Advanced Materials Research, 71-73, 661-664.

Pietrelli L., Bellomo B., Fontana D. and Montereali M.R. (2002). Rare earths recovery from NiMH spent batteries. Hydrometallurgy, 66, 135-139.

Pradhan J.K. and Kumar S. (2012). Metals bioleaching from electronic waste by Chromobacterium violaceum and Pseudomonads sp. Waste Management Research, 30, 11511159.

Priya A. and Hait S. (2017). Comparative assessment of metallurgical recovery of metals from electronic waste with special emphasis on bioleaching. Environmental Science and Pollution Research.

Qu Y. and Lian B. (2013). Bioleaching of rare earth and radioactive elements from red mud using Penicillium tricolor RM-10. Bioresource Technology, 136, 16-23.

Quinet P., Proost J. and Van Lierde A. (2005). Recovery of precious metals from electronic scrap by hydrometallurgical processing routes. Minerals and Metallurgical Processing, 22, 17-22.

Reed D.W., Fujita Y., Daubaras D.L., Jiao Y. and Thompson V.S. (2016). Bioleaching of rare earth elements from waste phosphors and cracking catalysts. Hydrometallurgy, 166, 3440.

Rubin R.S., Castro M.A.S.de, Brandão D., Schalch V. and Ometto A.R. (2014). Utilization of life cycle assessment methodology to compare two strategies for recovery of copper from printed circuit board scrap. Journal of Cleaner Production, 64, 297-305.

Sand W., Gehrke T., Jozsa P.G. and Schippers A. (2001). (Bio)chemistry of bacterial leaching-direct vs. indirect bioleaching. Hydrometallurgy, 59, 159-175.

Sheel A. and Pant D. (2018). Recovery of gold from electronic waste using chemical assisted microbial biosorption (hybrid) technique. Bioresource Technology, 247, 1189-1192.

Sheng P.P. and Etsell T.H. (2007). Recovery of gold from computer circuit board scrap using aqua regia. Waste Management and Research, 25, 380-383.

Shin D., Kim J., Kim B., Jeong J. and Lee J. (2015). Use of phosphate solubilizing bacteria to leach rare earth elements from monazite-bearing ORE. Minerals, 5, 189-202.

Sum E.Y.L. (1991). The Recovery of Metals from Electronic Scrap. Journal of the Minerals Metals \& Materials Society (JOM), 43, 53-61.

Sun Z.H.I., Xiao Y., Sietsma J., Agterhuis H., Visser G. and Yang Y. (2015). Characterisation of metals in the electronic waste of 
complex mixtures of end-of-life ICT products for development of cleaner recovery technology. Waste Management, 35, 227235.

Tan Q. and Li J. (2015). Recycling metals from wastes: A novel application of mechanochemistry. Environmental Science \& Technology, 49, 5849-5861.

Tanskanen P. (2013). Management and recycling of electronic waste. Acta Materialia, 61, 1001-1011.

Toffolet R. (2016). Chapter 1 - WEEE management. In WEEE Recycling, Chagnes A., Cote G., Ekberg C., Nilsson M. and Retegan T. (Eds.), Elsevier, pp. 1-30.

Tsydenova O. and Bengtsson M. (2011). Chemical hazards associated with treatment of waste electrical and electronic equipment. Waste Management, 31, 45-58.

Tuncuk A., Stazi V., Akcil A., Yazici E.Y. and Deveci H. (2012). Aqueous metal recovery techniques from e-scrap: Hydrometallurgy in recycling. Minerals Engineering, 25, 2837.

Tunsu C. and Retegan T. (2016). Chapter 6 - Hydrometallurgical processes for the recovery of metals from WEEE. In: WEEE Recycling, Elsevier, pp. 139-175.

Tunsu C., Petranikova M., Gergorić M., Ekberg C. and Retegan T. (2015). Reclaiming rare earth elements from end-of-life products: A review of the perspectives for urban mining using hydrometallurgical unit operations. Hydrometallurgy, 156, 239-258.

Ueberschaar M., Geiping J., Zamzow M., Flamme S. and Rotter V.S. (2017). Assessment of element-specific recycling efficiency in WEEE pre-processing. Resources Conservation Recycling, 124, 25-41.

Umicore (2018, February 12). Retrieved from http://pmr.umicore.com/

Veit H.M., Pereira C.C.de and Bernardes A.M. (2002). Using mechanical processing in recycling printed wiring boards. Journal of Management, 54, 45-47.

Veit H.M., Bernardes A.M., Ferreira J.Z., Tenório J.A.S. and Malfatti C.de.F. (2006). Recovery of copper from printed circuit boards scraps by mechanical processing and electrometallurgy. Journal of Hazardous Materials, 137, 17041709.

Vijayaraghavan K. and Yun Y.-S. (2008). Bacterial biosorbents and biosorption. Biotechnology Advances, 26, 266-291.

Wang J. and Chen C. (2009). Biosorbents for heavy metals removal and their future. Biotechnology Advances, 27, 195-226.

Wang R. and Xu Z. (2014). Recycling of non-metallic fractions from waste electrical and electronic equipment (WEEE): A review. Waste Management, 34, 1455-1469.

Wang J., Bai J., Xu J. and Liang B. (2009). Bioleaching of metals from printed wire boards by Acidithiobacillus ferrooxidans and Acidithiobacillus thiooxidans and their mixture. Journal of Hazardous Materials, 172, 1100-1105.

Wang M., Tan Q., Chiang J.F. and Li J. (2017). Recovery of rare and precious metals from urban mines-A review. Frontiers of Environmental Science \& Engineering, 11.

Widmer R., Oswald-Krapf H., Sinha-Khetriwal D., Schnellmann M. and Böni H. (2005). Global perspectives on e-waste. Environmental Impact Assessment Review, 25, 436-458.

Yang H., Liu J. and Yang J. (2011). Leaching copper from shredded particles of waste printed circuit boards. Journal of Hazardous Materials, 187, 393-400.
Yang J., Wu Y. and Li J. (2012). Recovery of ultrafine copper particles from metal components of waste printed circuit boards. Hydrometallurgy, 121-124, 1-6.

Yang T., Xu Z., Wen J. and Yang L. (2009). Factors influencing bioleaching copper from waste printed circuit boards by Acidithiobacillus ferrooxidans. Hydrometallurgy, 97, 29-32.

Yang Y., Chen S., Li S., Chen M., Chen H. and Liu B. (2014). Bioleaching waste printed circuit boards by Acidithiobacillus ferrooxidans and its kinetics aspect. Journal of Biotechnology, 173, 24-30.

Yu J., Williams E. and Ju M. (2009). Review and prospects of recycling methods for waste printed circuit boards. In Sustainable Systems and Technology, 2009. ISSST'09. IEEE International Symposium On, (IEEE), pp. 1-5.

Zhang L. and Xu Z. (2016). A review of current progress of recycling technologies for metals from waste electrical and electronic equipment. Journal of Cleaner Production, 127, 19-36.

Zhang S. and Forssberg E. (1997). Mechanical separation-oriented characterization of electronic scrap. Resources Conservation Recycling, 21, 247-269.

Zhang Y., Liu S., Xie H., Zeng X. and Li J. (2012). Current status on leaching precious metals from waste printed circuit boards. Procedia Environmental Sciences, 16, 560-568.

Zhu N., Xiang Y., Zhang T., Wu P., Dang Z., Li P. and Wu J. (2011). Bioleaching of metal concentrates of waste printed circuit boards by mixed culture of acidophilic bacteria. Journal of Hazardous Materials, 192, 614-619. 